\title{
Left Ventricular Dysfunction in Breast Cancer Patients Receiving Trastuzumab: An Observational Study in a Cohort of Iraqi Breast Cancer Patients
}

\author{
Musaab R. Al-Bayati \\ MB.Ch.B, FICMS, MRCP, ESMO C. \\ Dept. of Medical Oncology, Alhabobi hospital, Thiqar, Iraq \\ Email : mousabraji@yahoo.com
}

\begin{abstract}
Background : Cardiotoxicity is a well recognized adverse event of trastuzumab. This study was designed to evaluate the frequency of decline in left ventricular ejection fraction (LVEF) to less than 50\% in patients with breast cancer who have received trastuzumab in a daily practice setting.
\end{abstract}

Methods : Retrospective observational study of 116 patients with HER2 positive breast cancer treated with trastuzumab in one center between May 2012 and January 2017.

Results : Left ventricular ejection fraction decline to less than $50 \%$ was observed in 7 patients $(6 \%)$. Patients above 70 years of age have the highest frequency of LVEF decline (33\%). All events of LVEF decline was reported in the first six months of treatment. Prolonged administration of trastuzumab beyond one year was not associated with adverse cardiac events. Previous anthracycline exposure and chest irradiation was not found to be associated with LVEF decline.

Conclusions : Events of LVEF decline to less than 50\% associated with trastuzumab use seems to be slightly higher in general daily practice than in clinical trial setting, especially in patients above 70 years, calling for better patient selection. First year of trastuzumab therapy carries the highest risk of cardiac events which necessitates a close cardiac monitoring, thereafter, periodic LVEF measurements can be reduced to reduce the costs.

Keywords : Breast cancer, Ejection fraction, Trastuzumab

\section{Introduction}

Overexpression of the HER2 protein (a transmembrane tyrosine kinase receptor involved in cell differentiation and proliferation), amplification of the HER2 gene, or both occur in approximately 15 to 20 percent of breast cancers $[1,2]$. Trastuzumab is a humanized monoclonal antibody with specificity for the extracellular domain of HER-2 [3]. In 1998, trastuzumab was approved by the US Food and Drug Administration for the treatment of metastatic HER2overexpressing invasive breast cancer when clinical trials confirmed that addition 
of trastuzumab to standard chemotherapy improves disease-free survival (DFS) and overall survival (OS) in these patients [46]. Subsequent trials of trastuzumab in early breast cancer showed a reduction of the recurrence risk of about $50 \%$ and a $30 \%$ reduction in mortality [7-11]. This led to the approval of trastuzumab by the US Food and Drug Administration for the adjuvant treatment of early HER2overexpressing invasive breast cancer [12]. Although trastuzumab was generally well-tolerated, it is use in clinical trials was associated with increased risk of cardiotoxicity [7, 10, 13], which was attributed to the expression of HER2 by myocardial cells in response to stress [14]. In the clinical trial setting, two metaanalyses which included 11,991 patients with early breast cancer and 1497 patients with metastatic breast cancer treated with trastuzumab showed that the relative risk of congestive heart failure (CHF) was 5.11 (90\% confidence interval [CI]: 3.00-8.72) in the adjuvant setting [15], and $3.49(90 \%$ confidence interval $[\mathrm{CI}]: 1.88$ to 6.47 ) in the metastatic setting [16]. As most clinical trials exclude patients with advanced age and pre-existing heart disease, the risk of trastuzumab related cardiotoxicity in daily practice may be higher and may be related to patients age, presence of cardiovascular risk factors or even to geographical variations [17-22]. In this study, a group of Iraqi breast cancer patients from single institution were studied for the incidence of trastuzumab related cardiotoxicity, timing, severity and risk factors.

\section{Patients and Methods}

A retrospective observational study of patients with HER2-positive breast cancer who have received trastuzumab between May 2012 and January 2017 in Thiqar medical oncology department.

A total of 116 patients with HER2-positive breast cancer have received trastuzumab during the study period, 79 patients $(68 \%)$ as adjuvant therapy and 37 patients (32\%) for metastatic breast cancer.

According to our policy for administration of trastuzumab, a baseline transthoracic echocardiography must be done before the first dose of trastuzumab and the LVEF determined. The LVEF had to be higher than $55 \%$ to allow patients to start treatment with trastuzumab. Thereafter, measurements had to be performed at least every 3 months until end of trastuzumab treatment. Also, patients with Uncontrolled severe hypertension, recent (less than 6 months) acute coronary syndrome, and, uncontrolled arrhythmia are considered not eligible for trastuzumab.

Trastuzumab was given every 21 days at a dose of $8 \mathrm{mg} / \mathrm{kg}$ for the first dose and 6 $\mathrm{mg} / \mathrm{kg}$ for subsequent doses.

\section{Definition of Endpoints}

We used an LVEF less than $50 \%$ as a cutoff to define patients with cardiotoxicity. Patients with LVEF decline $>10 \%$ from baseline (but NOT to less than 50\%) were not defined as having cardiotoxicity 


\section{Results}

\begin{tabular}{|c|c|}
\hline Characteristic & No $(\%)$ \\
\hline \multicolumn{2}{|l|}{ Age at diagnosis (Years) } \\
\hline$<35$ & $12(10.4)$ \\
\hline $35-44$ & $40(34.5)$ \\
\hline $45-54$ & $38(32.7)$ \\
\hline 55- 64 & $16(13.7)$ \\
\hline $65-75$ & $10(8.7)$ \\
\hline \multicolumn{2}{|l|}{ Sex } \\
\hline Female & $116(100)$ \\
\hline Male & $0(0)$ \\
\hline \multicolumn{2}{|l|}{ Location of the tumor } \\
\hline Right breast & $63(54)$ \\
\hline Left breast & $53(46)$ \\
\hline \multicolumn{2}{|l|}{ Hormone Receptor Status } \\
\hline Hormone Receptor positive & $63(54)$ \\
\hline Hormone Receptor negative & $53(46)$ \\
\hline \multicolumn{2}{|l|}{ Chest wall Radiotherapy } \\
\hline Yes & $65(56)$ \\
\hline No & $51(44)$ \\
\hline \multicolumn{2}{|l|}{ Trastuzumab therapy } \\
\hline Adjuvant & $79(68)$ \\
\hline Metastatic disease & $37(32)$ \\
\hline \multicolumn{2}{|l|}{ Chemotherapy Received } \\
\hline Anthracyclines without taxanes (A) & $20(16.2)$ \\
\hline Anthracyclines and taxanes (AT) & $80(70.2)$ \\
\hline Non-anthracyclines (Non-A) & $16(13.6)$ \\
\hline \multicolumn{2}{|l|}{ Duration of trastuzumab therapy } \\
\hline$<6$ months & $14(12)$ \\
\hline 6 months - 1 year & $76(65.5)$ \\
\hline 1 year - 2 year & $20(17.2)$ \\
\hline$>2$ years & $6(5.1)$ \\
\hline Overall & 116 \\
\hline
\end{tabular}


Table 1 lists the baseline characteristics of the patients. The median age of patients in the study was 46 (Range $25-74$ ) years. More than $75 \%$ of patients were less than 55 years of age and less than $5 \%$ above 70 years. All patients were females. About $86 \%$ of the patients have received anthracyclines at some point, however, none of the patients have received concomitant anthracycline and trastuzumab.

From the total of 116 patients, Seven patients (6\%) developed decline of LVEF to less than $50 \%$. Table 2 shows the characteristics of patients who develops LVEF decline.

\begin{tabular}{|c|c|c|c|c|c|c|}
\hline Patient no. & $\begin{array}{c}\text { Age } \\
\text { (Year) }\end{array}$ & $\begin{array}{c}\text { Timing of } \\
\text { LVEF } \\
\text { decline }\end{array}$ & $\begin{array}{l}\text { Tumor } \\
\text { location }\end{array}$ & $\begin{array}{c}\text { Chest } \\
\text { wall RT }\end{array}$ & $\begin{array}{l}\text { Chemo } \\
\text { received }\end{array}$ & Symptom \\
\hline 1 & 53 & 2 months & $\mathrm{R}$ & Yes & A & Yes \\
\hline 2 & 32 & 6 months & $\mathrm{L}$ & Yes & $\mathrm{AT}$ & No \\
\hline 3 & 69 & 5 months & $\mathrm{L}$ & No & AT & Yes \\
\hline 4 & 60 & 6 months & $\mathrm{R}$ & Yes & AT & No \\
\hline 5 & 73 & 3 months & $\mathrm{R}$ & Yes & $\mathrm{A}$ & Yes \\
\hline 6 & 74 & 6 months & $\mathrm{L}$ & Yes & $\mathrm{AT}$ & No \\
\hline 7 & 52 & 4 months & $\mathrm{L}$ & No & NA & Yes \\
\hline
\end{tabular}

Most events occurred in patients above 50 years of age. Only one patient below 50 years of age develops decline in LVEF. Two out of six patients (33.3\%) above 70 years of age given trastuzumab develops decline in LVEF to less than $50 \%$.

Most patients develops LVEF decline within the first 6 months with a mean of 4.5 months (Range $2-6$ months). (2 patients within the first 3 months and 5 patients within the first 6 months). None of the patients who continued trastuzumab beyond 6 months develops decline in LVEF.

Four patients have left breast cancer, two of them have received chest wall irradiation, and three patients have right breast cancer all of them received chest wall irradiation.

Six patients have received anthracycline, four of them, with taxanes, while only one patient who have never received anthracycline develops LVEF decline.

Four patients $(3.5 \%)$ have symptoms of LV dysfunction ranging from NYHA CLASS I to III, while three patients $(2.5 \%)$ have asymptomatic LVEF decline to less than $50 \%$. Five patients discontinued trastuzumab permanently when LVEF decline $<50 \%$ observed, while two patients have been rechallenged with the drug after two months treatment of heart failure and improvement of LV function, but, both patients develops further decline in LV function after re-introduction of trastuzumab and discontinued treatment permanently. 
Table 3 gives the occurrence of trastuzumab-related LVEF decline to less than $50 \%$ according to age and other selected baseline characteristics with the corresponding $\mathrm{P}$ value.

\begin{tabular}{|c|c|c|c|}
\hline Characteristic & No & $\begin{array}{l}\text { No (\%) with } \\
\text { LVEF }<50 \%\end{array}$ & P value \\
\hline \multicolumn{4}{|l|}{ Age at diagnosis (Years) } \\
\hline$<\mathbf{5 0}$ & 72 & $1(1.4)$ & \multirow{3}{*}{$<0.05$} \\
\hline $50-70$ & 38 & $4(10.5)$ & \\
\hline$>70$ & 6 & $2(33.3)$ & \\
\hline \multicolumn{4}{|l|}{ Hormone Receptor Status } \\
\hline Hormone Receptor positive & 63 & $3(4.7)$ & \multirow[t]{2}{*}{$>0.05$} \\
\hline Hormone Receptor negative & 53 & $4(7.5)$ & \\
\hline \multicolumn{4}{|l|}{ Chest wall Radiotherapy } \\
\hline Yes & 65 & $5(7.6)$ & \multirow[t]{2}{*}{$>0.05$} \\
\hline No & 51 & $2(3.9)$ & \\
\hline \multicolumn{4}{|l|}{ Trastuzumab therapy } \\
\hline Adjuvant & 79 & 4 & \multirow[t]{2}{*}{$>0.05$} \\
\hline Metastatic disease & 37 & 3 & \\
\hline \multicolumn{4}{|l|}{ Chemotherapy Received } \\
\hline Anthracyclines without taxanes (A) & 20 & $2(10)$ & \multirow{3}{*}{$<0.05$} \\
\hline Anthracyclines and Taxanes (AT) & 80 & $4(5)$ & \\
\hline Non-anthracyclines (NA) & 16 & $1(6.2)$ & \\
\hline
\end{tabular}

\section{Discussion}

In this study, which was carried out in a non-trial clinical practice setting, the incidence of LVEF decline to less than $50 \%$ was found to be $6.0 \%$, with $3.5 \%$ incidence of symptomatic heart failure. In the HERA trial, the largest trial of adjuvant trastuzumab, the incidence of symptomatic congestive heart failure was $1.73 \%$ [7]. In the B-31 trial, the incidence of decline in LVEF and congestive heart failure was $4.1 \%$ [10]. However, in a cohort of canadian patients received trastuzumab in a nontrial setting, the incidence of congestive heart failure and LVEF decline to $<50 \%$ was $6.0 \%$ [23], which is exactly similar to our results. The BCIRG-006 trial have reported higher rates of cardiotoxicity, $18.6 \%$ for ACTH protocol and $9.4 \%$ for $\mathrm{TCH}$ protocol [13]. However, these results represents any decline in LVEF including subclinical loss of mean LVEF (defined as $>10 \%$ relative loss). In our study, we defined cardiotoxicity as a decline of LVEF to $<50 \%$, and not included patients with a relative decline of LVEF.

Risk factors for trastuzumab cardiotoxicity have been studied by several investigators. Increasing age is 
the most important risk factor for developing trastuzumab cardiotoxicity [24], although, other authors suggests that baseline LVEF [25], Obesity and Hypertension are also important [26]. In this study, we found a significant association between patient age and the development of cardiac toxicity with a significant $\mathrm{P}$ value. Decline in LVEF < $50 \%$ were reported in two out of six patients above 70 years of age, four out of thirty eight patients between 50 to 70 years, and, only one patient out of seventy two below 50 years of age. These data are in line with an Italian cohort study that included 681 women with breast cancer [18].

Studies suggest that the first 3months of trastuzumab therapy account for most of the cardiotoxic events, and that cardiotoxicity occurring more than 6months after start of trastuzumab is rare [32, 33]. A Dutch study which included 230 patients treated with trastuzumab found that $84.8 \%$ of the patients who discontinue the drug due to cardiotoxicity do so in the first six months, and that the first LVEF drop was seen at a median of 2.5 months (range: 0.7-10.3 months) [1]. Our results shows that all events of $\mathrm{LV}$ dysfunction occurred in the first 6 months, and none of the patients who continued trastuzumab develops decline in LVEF even after 3 years of continuous treatment suggesting that trastuzumab cardiotoxicity is not dose dependent, and that cardiac monitoring should focus on the first year of treatment.

\section{Conclusions}

In this observational study, we found that the frequency of decline in LVEF to less than $50 \%$ in patients receiving trastuzumab is $6 \%$. Patients $>70$ years of age are at the highest risk to develop this complication. Also, we found that all patients develops this complication in the first six months of trastuzumab treatment, necessitating a closer cardiac monitoring in this period.

\section{References}

1. Seferina SC, de Boer M, Derksen MW et al. Cardiotoxicity and Cardiac Monitoring During Adjuvant Trastuzumab in Daily Dutch Practice: A Study of the Southeast Netherlands Breast Cancer Consortium. Oncologist 2016 May;21(5):555-62.

2. Bonifazi M, Franchi M, Rossi M et al. Trastuzumab-related cardiotoxicity in early breast cancer: a cohort study. Oncologist 2013;18(7):795-801

3. Burstein HJ. The distinctive nature of HER2-positive breast cancers. N Engl J Med 2005;353:1652-1654.

4. Rossi M, Carioli G, Bonifazi $\mathrm{M}$ et al. Trastuzumab for HER2+ metastatic breast cancer in clinical practice: Cardiotoxicity and overall survival. Eur $\mathbf{J}$ cancer 2016 Jan;52:41-9.

5. Chen J, Long JB, Hurria A et al. Incidence of Heart Failure or Cardiomyopathy After Adjuvant Trastuzumab Therapy for Breast Cancer. J Am Coll Cardiol. 2012; 60:2504-2512

6. Slamon DJ, Leyland-Jones B, Shak $\mathrm{S}$ et al. Use of chemotherapy plus a monoclonal antibody against HER2 for metastatic breast cancer that overexpresses HER2.NEngl JMed2001;344:783-792.

7. Piccart-Gebhart MJ, Procter M, Leyland-Jones B et al. Trastuzumab after adjuvant chemotherapy in HER2-positive breast cancer. N Engl J Med 2005; 
353:1659-1672.

8. Perez EA, Romond EH, Suman VJ et al. Trastuzumab plus adjuvant chemotherapy for human epidermal growth factor receptor 2-positive breast cancer: Planned joint analysis of overall survival from NSABP B-31 and NCCTG N9831. J Clin Oncol 2014;32:3744-3752.

9. Goldhirsch A, Piccart-Gebhart M, Procter M, et al. HERA TRIAL: 2 years versus 1 year of trastuzumab after adjuvant chemotherapy in women with HER2positive early breast cancer at 8 years of median follow up. Cancer Research 2012;72:S5-2.

10. Romond E, Perez E, Bryant J, et al. Trastuzumab plus adjuvant chemotherapy for operable HER2-positive breast cancer. N Engl J Med 2005;353:1673-1684.

11. Joensuu H, Kellokumpu-Lehtinen $\mathrm{P}$, Bono $\mathrm{P}$, et al. Adjuvant docetaxel or vinorelbine with or without trastuzumab for breast cancer. N Engl J Med 2006;354:809820.

12. National Cancer Institute. FDA approval for trastuzumab.Available at http://www.cancer.gov/ aboutcancer/treatment/drugs/fda-trastuzumab.

13. Slamon D, Eiermann W, Robert $\mathrm{N}$, et al. Adjuvant trastuzumab in HER2positive breast cancer. $\mathrm{N}$ Engl $\mathrm{J}$ Med 2011;365:1273- 83.

14. Crone SA, Zhao YY, Fan L et al. ErbB2 is essential in the prevention of dilated cardiomyopathy. Nat Med 2002;8:459-465.

15. Moja L, Tagliabue L, Balduzzi S et al. Trastuzumab containing regimens for early breast cancer. Cochrane Database Syst Rev 2012 Apr 18;(4):CD006243.

16. Balduzzi S, Mantarro S, Guarneri $\mathrm{V}$ et al. Trastuzumab containing regimens for metastatic breast cancer. Cochrane Database Syst Rev 2014 Jun 12;(6):CD006242..
17. Serrano C, Cortes J, De MattosArruda L et al. Trastuzumab-related cardiotoxicity in the elderly:A role for cardiovascular risk factors. Ann Oncol 2012;23:897-902.

18. Ayres LR, de Almeida Campos MS, de Oliveira Gozzo T et al. Trastuzumab induced cardiotoxicity in HER2 positive breast cancer patients attended in a tertiary hospital. Int J Clin Pharm. 2015 Apr;37(2):365-72.

19. Tarantini L, Gori $\mathrm{S}$, Faggiano $\mathrm{P}$ et al. Adjuvant trastuzumab cardiotoxicity in patients over 60 years of age with early breast cancer: A multicenter cohort analysis. Ann Oncol 2012;23:3058 -3063.

20. Tsai HT, Isaacs C, Fu AZ et al. Risk of cardiovascular adverse events from trastuzumab in elderly persons with breast cancer: a population-based study. Breast Cancer Res Treat. 2014 Feb;144(1):163-70.

21. Shih V, Chan A, Chiang $J$ et al. Cardiotoxicity risks of adjuvant trastuzumab in Asian breast cancer patients. J Clin Oncol 2009 May 20;27(15_suppl):561.

22. Hsu-Chih Chien, Yea-Huei Kao Yang, Jane P. F. Ba. Trastuzumab-Related Cardiotoxic Effects in Taiwanese Women.

A Nationwide Cohort Study. JAMA Oncol. 2016;2(10):1317-1325.

23. Withrow D, Verma $S$, Dent $R$ et al. Trastuzumab-mediated cardiotoxicity in the nontrial setting : Evaluation of patients receiving adjuvant trastuzumab at an academic center. J Clin Oncol. 2009 May 20;27(15_suppl):e11550.

24. Seidman A, Hudis C, Pierri MK, et al. Cardiac dysfunction in the trastuzumab clinical trials experience. J Clin Oncol 2002; 20:1215-1221.

25. Guarneri V, Lenihan DJ, Valero $\mathrm{V}$, et al. Long-term cardiac tolerability of trastuzumab in metastatic breast cancer: The M.D. Anderson Cancer Center experience. J Clin Oncol 2006; 24:4107-4115.

26. Adamo V, Ricciardi GR, Adamo $\mathrm{B}$, et al. The risk of toxicities from 
Thi-Qar Medical Journal (TQMJ): Vol.(15), No.(1), 2018

Web Site: https://jmed.utq.edu.iq

Email:utjmed@utq.edu.iq

trastuzumab, alone or in combination, in an elderly breast cancer population. Oncology 2014; 86:16-21.

27. Pietras RJ, Poen JC, Gallardo D, Wongvipat PN, Lee HJ, Slamon DJ. Monoclonal antibody to HER-2/neu receptor modulates repair of radiationinduced DNA damage and enhances radiosensitivity of human breast cancer cells overexpressing this oncogene. Cancer Res. 1999;59:1347-55.

28. Law AB, Evans T, Hayward RL, Higgins GS, Murray KL, Summers D, et al. Possible radiation sensitisation by trastuzumab leading to radiation-induced myelitis. Breast Care (Basel) 2009;4:40-2.

29. Tan-Chiu E, Yothers G, Romond E, Geyer CE, Jr, Ewer M, Keefe D, et al. Assessement of cardiac dysfunction in a randomized trial comparing doxorubicin and cyclophosphamyde followed by paclitaxel, with or without trastuzumab as adjuvant therapy in node positive, human epidermal growth factor receptor 2-overexpressing breast cancer: NSABP B-31. J Clin Oncol. 2005;23:7811-19.

30. Halyard MY, Pisansky TM, Dueck AC, Suman V, Pierce L, Solin L, et al. Radiotherapy and adjuvant trastuzumab in operable breast cancer: tolerability and adverse event data from the NCCTG Phase III Trial N9831. J Clin Oncol. 2009;27:2638-44.

31. Bowles EJ, Wellman R, Feigelson $\mathrm{HS}$, et al. Risk of heart failure in breast cancer patients after anthracycline and trastuzumab treatment: a retrospective cohort study. J Natl Cancer Inst. 2012;104:1293-1305.

32. Guglin M, Cutro R, Mishkin JD. Trastuzumab induced cardiomyopathy. J Card Fail 2008;14:437-444.

33. Tarantini L, Cioffi G, Gori $\mathrm{S}$ et al. Trastuzumab adjuvant chemotherapy and cardiotoxicity in real world women with breast cancer. J Card Fail 2012;18:113-11

\section{أنخفاض وظيفة البطين الأيسر لاى مرضى سرطان الثي المعالجين بعقار التراستوزوماب}




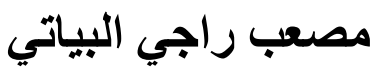

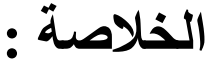

يعتبر هبوط وظيفة البطين الايسر من اهم الاعراض الجانبية المصاحبة لاستخدام عقار تر استوزوماب من قبل مرضى سرطان الثذي.

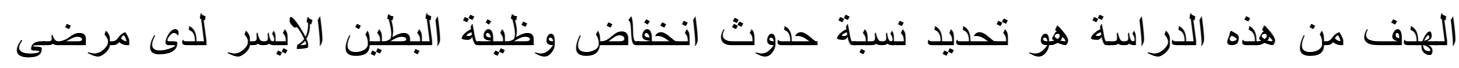

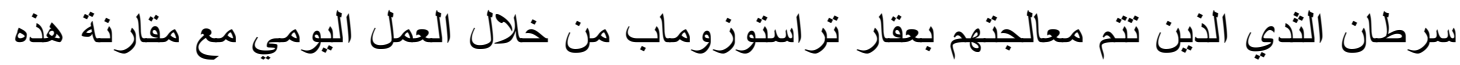
النسبة مع النسب المسجلة في الدر اسات البحثية العالمية.

شملت الدراسة 117 مريضة بسرطان الثدي تمت معالجتهم بعقار التراستوزوماب في وحدة التربة

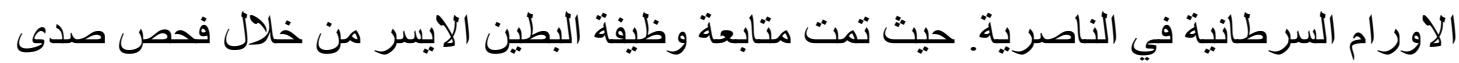

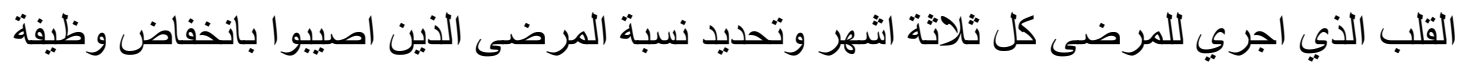
البطين الايسر الى اقل من •0 بالمئُة.

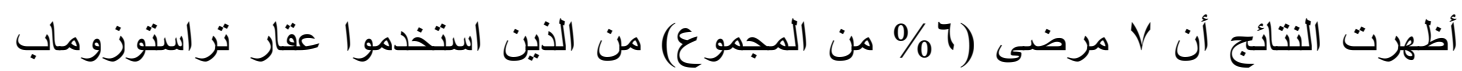

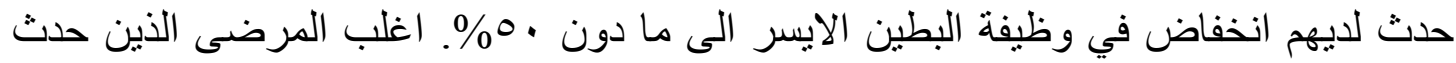

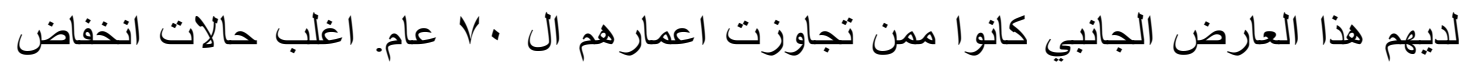

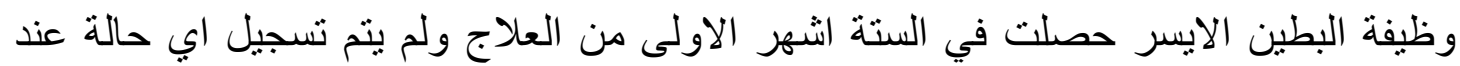

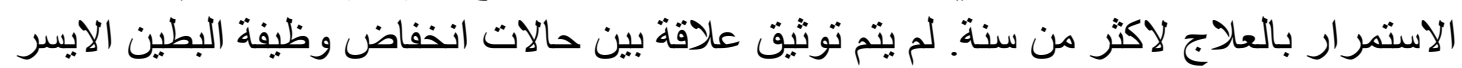

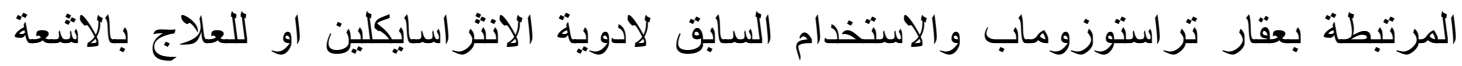

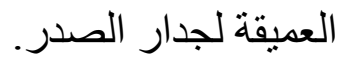

خلصت الدراسة أن نسب انخفاض وظيفة البطين الايسرى لدى المرض المعالجين بعقار

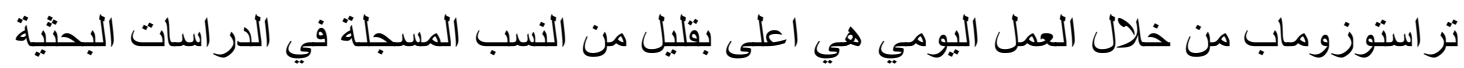
و هذا يعود الى الاختبار الاقيق للمرضى في اليودي هي الدراسات البحثية مقارنة بالعمل اليومي. 